\title{
Do Medical Students Have Sufficient Opportunity to Implement Their Clinical Skill in Primary Care Setting?
}

\author{
Marita Fadhilah, Fika Ekayanti, Risahmawati \\ Department of Community Medicine \\ Medical Study Program, Faculty of Medicine and Health Sciences \\ Syarif Hidayatullah State Islamic University \\ Jakarta, Indonesia \\ maritafadhilah@uinjkt.ac.id
}

\begin{abstract}
Universal health coverage requires tiered referral system that makes majority basic health service is conducted in primary care setting. To support it, on 2012 Indonesia Medical Council has assigned Indonesia medical doctor standard competency (SKDI). Medical faculty should teach medical students with those entire competencies that must be mastered by medical doctor. We have not found national data about the evaluation of conformity of clinical skill teaching and community needs in primary care setting. Therefore we need to explore whether medical students could implement their clinical skill in primary care setting, and factors affecting its implementation. This study was a descriptive study with cross sectional approach. Data collected from October to November 2014. A set of questionnaire was given to students' group, inquired list of clinical skills those have learned during academic and clinical phase, also clinical skills that they implemented in primary health care (PHC). A total of $\mathbf{1 0}$ groups (contained five medical students each group) in 10 PHC Tangerang District during community medicine rotation were involved in this study. In total 178 competencies were collected from 10 student groups. Students revealed that $77.53 \%$ clinical skill had been taught during academic and clinical phase, whilst they just implemented 19.66\% clinical skills in PHC during community medicine rotation. Clinical skills that students had less opportunity to implement were diagnosis and proposing additional examination. The major factors that affecting implementation clinical skill in PHC were limited drugs and tools also infrastructures $(21$ and 17 of total 95 cases). This study provided good feedback to medical institution and government. For medical institution it is recommended to cover some clinical skills that students have not been taught. For government should improve availability of drugs, tools and infrastructures in PHC. Despite students revealed that most of clinical skill had been taught during academic and clinical phase, they were lack of diagnosis and proposing additional examination implementation in PHC during community medicine rotation. The most factors affected were limited drugs and tools/equipment.
\end{abstract}

Keywords—clinical skills; primary health care; Indonesian Medical Doctor competency

\section{INTRODUCTION}

Since National Health Coverage (locally known as

This study was sponsored by Center for Research and Publication of Syarif Hidayatullah State Islamic University Jakarta, Indonesia.
Jaminan Kesehatan Nasional or JKN) was declared on January $1^{\text {st }} 2014$ by Indonesian Government, the universal health coverage mechanism was mandatory for all Indonesian people and primary health center (PHC) became health provider in primary care setting [1]. PHC is primary health care facility that provides community and personal health care. PHC as one of primary health care facility has important role in national health system.

Indeed, JKN requires enhancing of primary care and patient referral system, also health promotive and preventive to decrease disease morbidity and mortality. PHC is expected to be main gate for people accessing health care facility.

In PHC, doctor roles as gate keeper for people in its area on providing health care as personal approach. To solve patient and community health problems, doctor must perform their knowledge and clinical skills as well as has written in Indonesia doctor standard competency (locally known as Standar Kompetensi Dokter Indonesia or SKDI) that was assigned by Indonesia Medical Council on 2006 and was revised on 2012. Regarding SKDI 2012, there are list of diseases and clinical skills that are classified into four levels of competencies from first level to fourth level. Fourth level must be mastered by doctors since it requires them to identify patients' problems until giving prompt treatments including education to patients [2]. Thus, diseases and clinical skills that are classified in forth level must be managed comprehensively in primary care setting.

Since JKN and SKDI 2012 established, Indonesian Medical Association and Indonesia Ministry of Health have reported 155 diseases guidance book, which were classified in fourth level and doctor often manage those diseases in primary care setting. Beside this guidance, Indonesian Medical Association and Indonesia Ministry of Health have compiled fourth level of doctor clinical skills guidance book in primary care setting.

Competent doctor is final outcome from medical institution. Medical institution is mandatory to teach medical students with those fourth level diseases and clinical skills competencies, so doctors have mastered fourth competencies when they work in primary care setting. Health care service depends on quality of care that is provided by doctor. Until 
now there is no national evidence regarding implementation of clinical skills in primary care setting, for example PHC, and there is no national evidence whether medical institution have taught all clinical skills that are needed by doctor in primary care setting. Therefore we need to explore whether medical students could implement their clinical skill in primary care setting, and factors affecting its implementation.

\section{EDUCATIONAL CONTEXT}

\section{A. Clinical Skills Teaching in Medical Study Program, \\ Faculty of Medicine and Health Sciences, Syarif \\ Hidayatullah State Islamic University Jakarta, Indonesia}

Clinical skills teaching in our Medical Study Program is known as basic clinical skills (BCS), was taught since our Medical Study Program established on 2005 until present. BCS is taught since first year to third year in preclinical phase, 4 hours a week. In BCS, medical students are divided into 810 students each group, with undersupervision of 1 tutor. There are 7 clinical skills competencies that are taught, such as: performing anamnesis, physical examination, laboratory examination or other supporting examination and interpreting the result, procedural skills (for example: doing vein punction, antibiotic injection, etc), working and differential diagnosis, pharmacotheraphy, and nonpharmacotherapy including providing education to patient.

BCS teaching has two phases: first phase is since 2005 to 2012 and second phase is conducted after curriculum evaluation from 2012 to present. In first phase, we used Peyton's Four Steps approach [3] that was adopted from Faculty of Medicine Indonesia University. Peyton approach contains four steps as follow:

1. Demonstration: Tutor demonstrates clinical skills using normal speed and without comments.

2. Deconstruction: Tutor demonstrates clinical skills and explaining step by step.

3. Comprehension: Tutor demonstrates clinical skills and medical students describe step by step.

4. Performance: Medical students demonstrate clinical skills while describing step by step.

After curriculum reform, since 2012 to present, BCS teaching uses five steps below [4]:

1. Conceptualization: Medical students have to understand cognitive aspect of clinical skills assigned to them.

2. Visualization: Medical students have to pay attention to clinical demonstration from beginning to end of session.

3. Verbalization: Medical students have to listen how to perform clinical skills in second demonstration.

4. Practice: Medical students have to practice clinical skills after seeing clinical skills demonstration, listening explanation step by step, and repeat it.

5. Correction and reinforcement: If medical students perform wrong step, give correction and constructive feedback.

\section{B. Indonesia Doctor Competency and Indonesia Doctor Standard Competency [2]}

To get practice license, medical students have to pass National Doctor Competency Examination (since 2014 known as National Medical Student Competency Examination) that is conducted by medical doctor association and medical institution [5]. This competency examination refers to Indonesia doctor standard competency (locally known as Standar Kompetensi Dokter Indonesia or SKDI). SKDI was published by Indonesia Medical Council as nondepartment institution assigned its special task in medical aspects. On 2006, SKDI was published in the first time.

Based on SKDI, doctors have to master standard competency if they want to practice in primary health care facility for solving community health problems. SKDI was completed with list of health problems, disease, and clinical skills, also competency lever for each disease and clinical skill. All medical institutions and collegiums comprehensively had reviewed SKDI. After SKDI was declared, all medical institutions reformed their curriculum become competency based curriculum.

Based on evaluation and requirement of medical institution, also to cover community health problems and needs, SKDI was modified and revised on 2012. The modification was conducted in level of doctor competency, list of disease, and clinical skills. SKDI 2012 is standard reference for doctor practice in community.

On SKDI 2012, doctor competency contains seven competency areas, such as: noble professionalism; selfawareness and self-development; effective communication; information management; scientific-based of medical science; clinical skill, and health problem management. Each competency translates competency component that consists of core competencies and expected outcomes from medical doctor graduates. In addition, there is an appendix consisting of a list of subjects scope, health problems, diseases, and clinical skills.

In revised edition of SKDI 2012, it contains 433 clinical skills with level competency 4A, 67 clinical skills with level competency 3, 84 clinical skills with level competency 2, and 42 clinical skills with level competency 1 . The description of the level competency that mentioned above on the doctor's clinical skills are:

1. Level competency 1 (Knows): Know and explain. Doctor graduates are able to master theoretical knowledge including the biomedical and psychosocial aspects, thus they able to explain to the patient/client and family, colleagues, and other professions on principles, indications, and complications that could be happened.

2. Level competency 2 (Knows How): Have seen or have been demonstrated. Doctor graduates master the theoretical knowledge of these skills with emphasis on clinical reasoning and problem solving, also have the opportunity to see and observe skills demonstrations or direct implementation to patients/community.

3. Level competency 3 (Shows): Have done or ever apply under supervision. Doctor graduates master the theoretical 
knowledge of these skills including the biomedical background and the psychosocial impact of these skill, also have opportunity to see and observe skills demonstration or direct implementation to the patient/community, and practice these skills in mannequin and/or standardized patient.

4. Level competency 4 (Does): Able to perform independently. Doctor graduates can demonstrate their skills by mastering all theories, principles, indications, steps of how to do, complications, and complications control. This level was divided into:

4A. Skills achieved after graduation.

4B. Proficiency that achieved after the completion of internship and/or Continuing Medical Education.

Thus, in SKDI 2012, the highest competency level of clinical skills is 4A. In order to improve the quality of health services, especially in improving the quality of doctors, the clinical skills that become the standard competency of primary care physician on SKDI are arranged in doctor's clinical skills guidance in primary care facility as reference for primary care physician in conducting primary health care.

\section{METHODS}

This study was a descriptive study with cross sectional approach by observing the activity in outpatient clinic 10 PHC that located in Tangerang district. Puskesmas become the center of activity for students who were persueing community medicine rotation. Data were collected from October to November 2014.

At data gathering phase, we involved representatives of clinical phase students of community medicine rotation at the PHC. There were a total of 10 student groups spread in 10 PHC (1 group consisted of 5 students). We provided a questionnaire that contained clinical skills according to SKDI 2012 to students. Students focused on clinical skills they have learned during the preclinical and clinical phase, and clinical skills they applied to patients for solving patient clinical problems. Data was analyzed using SPSS 16 software and we performed descriptive statistic in this study.

\section{RESULTS}

In total 178 cases were collected from 10 student groups. Students revealed that $77.53 \%$ clinical skill had been taught during academic/preclinical and clinical phase, whilst they just have implemented $19.66 \%$ clinical skills in PHC during community medicine rotation, as seen in table I.

Students stated that mostly all clinical skills had been taught during preclinical and clinical phase, except making diagnosis skills only 2 cases $(33.33 \%)$ that they had been taught and learned, as seen in table I and V.

For clinical skills implementation, student revealed that most of clinical skills had not been implemented at PHC during their 5 weeks rotation, but for communication and education skills they stated that they implemented 50\% (table I and II).
Clinical skills that students had less opportunity to implement were diagnosis and proposing additional examination (laboratory test, data interpretation, etc.) based on table I, IV, and V.

Physical examination skills were students had many experiences to do (69 cases; $38.76 \%$ ), especially in special senses physical examination. Unfortunately, students felt that they already had been taught physical examination skills about $85.51 \%$, but during the community medicine rotation at PHC they just implemented physical examination skills in 21 of 69 cases $(30.43 \%)$.

Beside doing physical examination, giving treatment to patient was the second clinical skills that students had many opportunity to do during 5 weeks community medicine rotation at PHC (63 cases). As physical examination skills, in giving treatment to patient only 7 cases $(11.11 \%)$ that students could give prompt treatment to patient, although $68.25 \%$ they already learned when preclinical and clinical phase.

TABLE I. TOTAL NUMBER OF CASES THAT STUDENTS MET, LEARNED, AND IMPLEMENTED

\begin{tabular}{|l|c|c|c|c|c|}
\hline & $\begin{array}{c}\text { Number of } \\
\text { cases }\end{array}$ & $\begin{array}{c}\text { Had been } \\
\text { taught (\%) }\end{array}$ & $\begin{array}{c}\text { Had not been } \\
\text { taught (\%) }\end{array}$ & $\begin{array}{c}\text { Had been } \\
\text { implemented } \\
(\%)\end{array}$ & $\begin{array}{c}\text { Had not been } \\
\text { implemented } \\
(\%)\end{array}$ \\
\hline $\begin{array}{l}\text { Communicati } \\
\text { on and } \\
\text { education } \\
\text { skills }\end{array}$ & 10 & $10(100)$ & $0(0)$ & $5(50)$ & $5(50)$ \\
\hline $\begin{array}{l}\text { Physical } \\
\text { examination } \\
\text { skills }\end{array}$ & 69 & 59 & $10(14.49)$ & $21(30.43)$ & $48(69.57)$ \\
\hline $\begin{array}{l}\text { Proposing } \\
\text { additional } \\
\text { examination } \\
\text { (laboratory } \\
\text { test, data } \\
\text { interpretation, } \\
\text { etc.) }\end{array}$ & 30 & $24(80)$ & $6(20)$ & $2(6.67)$ & $28(93.33)$ \\
\hline $\begin{array}{l}\text { Making } \\
\text { diagnosis }\end{array}$ & 6 & $\begin{array}{c}2 \\
(33.33)\end{array}$ & $4(66.67)$ & $0(0)$ & $6(100)$ \\
\hline $\begin{array}{l}\text { Giving } \\
\text { prompt } \\
\text { therapy }\end{array}$ & 63 & $\begin{array}{c}43 \\
(68.25)\end{array}$ & $20(31.75)$ & $7(11.11)$ & $56(88.89)$ \\
\hline Total & 178 & $\begin{array}{c}138 \\
(77.53)\end{array}$ & $40(22.47)$ & $35(19.66)$ & $143(80.34)$ \\
\hline
\end{tabular}

TABLE II. NUMBER OF CASES TOWARDS COMMUNICATION AND EDUCATION SKILLS THAT STUDENTS MET, LEARNED, AND IMPLEMENTED

\begin{tabular}{|c|c|c|c|c|c|}
\hline Systems & $\begin{array}{c}\text { Number of } \\
\text { cases }\end{array}$ & $\begin{array}{c}\text { Had been } \\
\text { taught }\end{array}$ & $\begin{array}{c}\text { Had not been } \\
\text { taught }\end{array}$ & $\begin{array}{c}\text { Had been } \\
\text { implemented }\end{array}$ & $\begin{array}{c}\text { Had not been } \\
\text { implemented }\end{array}$ \\
\hline $\begin{array}{c}\text { Psychiatry } \\
\text { anamnesis }\end{array}$ & 1 & 1 & 0 & 0 & 1 \\
\hline $\begin{array}{c}\text { Communica-- } \\
\text { tion }\end{array}$ & 5 & 5 & 0 & 3 & 2 \\
\hline $\begin{array}{c}\text { Reproduction } \\
\text { health } \\
\text { education }\end{array}$ & 2 & 2 & 0 & 2 & 0 \\
\hline $\begin{array}{c}\text { Endocrine } \\
\text { problem } \\
\text { education }\end{array}$ & 1 & 1 & 0 & 0 & 1 \\
\hline $\begin{array}{c}\text { Hematology } \\
\text { problem } \\
\text { education }\end{array}$ & 1 & 1 & 0 & 0 & 1 \\
\hline Total & 10 & 10 & $0(0 \%)$ & $5(50 \%)$ & $5(50 \%)$ \\
\hline
\end{tabular}


TABLE III. NUMBER OF CASES TOWARDS PHYSICAL EXAMINATION SKILLS THAT STUDENTS MET, LEARNED, AND IMPLEMENTED

\begin{tabular}{|c|c|c|c|c|c|}
\hline Systems & $\begin{array}{c}\text { Number } \\
\text { of cases }\end{array}$ & $\begin{array}{c}\text { Had been } \\
\text { taught }\end{array}$ & $\begin{array}{c}\text { Had not } \\
\text { been taught }\end{array}$ & $\begin{array}{c}\text { Had been } \\
\text { implemented }\end{array}$ & $\begin{array}{l}\text { Had not been } \\
\text { implemented }\end{array}$ \\
\hline Neurology & 11 & 9 & 2 & 1 & 10 \\
\hline Psychiatry & 2 & 2 & 0 & 0 & 2 \\
\hline $\begin{array}{l}\text { Special } \\
\text { senses }\end{array}$ & 14 & 11 & 3 & 0 & 14 \\
\hline $\begin{array}{l}\text { Cardiovas- } \\
\text { cular }\end{array}$ & 7 & 6 & 1 & 4 & 3 \\
\hline $\begin{array}{c}\text { Gastrointes- } \\
\text { tinal tract }\end{array}$ & 6 & 5 & 1 & 2 & 4 \\
\hline Nephrology & 1 & 1 & 0 & 0 & 1 \\
\hline $\begin{array}{l}\text { Reproduc- } \\
\text { tion system }\end{array}$ & 5 & 5 & 0 & 2 & 3 \\
\hline $\begin{array}{c}\text { Endocrino- } \\
\text { logy }\end{array}$ & 2 & 2 & 0 & 1 & 1 \\
\hline Hematology & 1 & 1 & 0 & 0 & 1 \\
\hline $\begin{array}{c}\text { Musculo- } \\
\text { skeletal }\end{array}$ & 3 & 3 & 0 & 1 & 2 \\
\hline Integument & 2 & 2 & 0 & 2 & 0 \\
\hline $\begin{array}{c}\text { Others } \\
\text { (pediatric) }\end{array}$ & 5 & 4 & 1 & 3 & 2 \\
\hline $\begin{array}{c}\text { Others } \\
\text { (adult and } \\
\text { emergency) }\end{array}$ & 8 & 7 & 1 & 4 & 4 \\
\hline Forensic & 2 & 1 & 1 & 1 & 1 \\
\hline Total & 69 & $\begin{array}{c}59 \\
(85.51 \\
\%)\end{array}$ & $\begin{array}{c}10 \\
(14.49 \%)\end{array}$ & $\begin{array}{c}21 \\
(30.43 \%)\end{array}$ & $\begin{array}{c}48 \\
(69.57 \%)\end{array}$ \\
\hline
\end{tabular}

TABLE IV. NUMBER OF CASES TOWARDS ADDITIONAL EXAMINATION SKILLS THAT STUDENTS MET, LEARNED, AND IMPLEMENTED

\begin{tabular}{|c|c|c|c|c|c|}
\hline Systems & $\begin{array}{c}\text { Number } \\
\text { of cases }\end{array}$ & \begin{tabular}{|c|}
$\begin{array}{c}\text { Had been } \\
\text { taught }\end{array}$ \\
\end{tabular} & $\begin{array}{c}\text { Had not } \\
\text { been taught }\end{array}$ & \begin{tabular}{|c|} 
Had been \\
implemented
\end{tabular} & $\begin{array}{l}\text { Had not been } \\
\text { implemented }\end{array}$ \\
\hline Neurology & 1 & 1 & 0 & 0 & 1 \\
\hline Respiratory & 3 & 3 & 0 & 2 & 1 \\
\hline $\begin{array}{l}\text { Cardiovas- } \\
\text { cular }\end{array}$ & 1 & 1 & 0 & 0 & 1 \\
\hline $\begin{array}{c}\text { Gastrointes- } \\
\text { tinal tract }\end{array}$ & 3 & 2 & 1 & 0 & 3 \\
\hline Nephrology & 3 & 3 & 0 & 0 & 3 \\
\hline $\begin{array}{l}\text { Reproduc- } \\
\text { tion system }\end{array}$ & 4 & 3 & 1 & 0 & 4 \\
\hline $\begin{array}{c}\text { Endocrino- } \\
\operatorname{logy}\end{array}$ & 1 & 1 & 0 & 0 & 1 \\
\hline Hematology & 6 & 5 & 1 & 0 & 6 \\
\hline Integument & 6 & 4 & 2 & 0 & 6 \\
\hline $\begin{array}{c}\text { Others } \\
\text { (adult and } \\
\text { emergency) }\end{array}$ & 1 & 1 & 0 & 0 & 1 \\
\hline Forensic & 1 & 0 & 1 & 0 & 1 \\
\hline Total & 30 & $\begin{array}{c}24 \\
(80 \%)\end{array}$ & $6(20 \%)$ & $2(6.67 \%)$ & $\begin{array}{c}28 \\
(93.33 \%)\end{array}$ \\
\hline
\end{tabular}

TABLE V. NUMBER OF CASES TOWARDS DIAGNOSIS SKILLS THAT STUDENTS MET, LEARNED, AND IMPLEMENTED

\begin{tabular}{|c|c|c|c|c|c|}
\hline Systems & $\begin{array}{c}\text { Number } \\
\text { of cases }\end{array}$ & $\begin{array}{c}\text { Had been } \\
\text { taught }\end{array}$ & $\begin{array}{c}\text { Had not } \\
\text { been taught }\end{array}$ & $\begin{array}{c}\text { Had been } \\
\text { implemented }\end{array}$ & $\begin{array}{c}\text { Had not been } \\
\text { implemented }\end{array}$ \\
\hline Psychiatry & 3 & 2 & 1 & 0 & 3 \\
\hline $\begin{array}{c}\text { Communi- } \\
\text { ty medicine }\end{array}$ & 3 & 0 & 3 & 0 & 3 \\
\hline Total & 6 & $\begin{array}{c}2 \\
(33.33 \%)\end{array}$ & $\begin{array}{c}4 \\
(66.67 \%)\end{array}$ & $0(0 \%)$ & $6(100 \%)$ \\
\hline
\end{tabular}

TABLE VI. NUMBER OF CASES TOWARDS THERAPHY SKILLS THAT STUDENTS MET, LEARNED, AND IMPLEMENTED

\begin{tabular}{|c|c|c|c|c|c|}
\hline Systems & $\begin{array}{l}\text { Number } \\
\text { of cases }\end{array}$ & \begin{tabular}{|c} 
Had been \\
taught
\end{tabular} & $\begin{array}{c}\text { Had not } \\
\text { been taught }\end{array}$ & \begin{tabular}{|c|} 
Had been \\
implemented
\end{tabular} & $\begin{array}{l}\text { Had not been } \\
\text { implemented }\end{array}$ \\
\hline $\begin{array}{c}\text { Special } \\
\text { senses }\end{array}$ & 8 & 5 & 3 & 1 & 7 \\
\hline Respiratory & 2 & 1 & 1 & 0 & 2 \\
\hline $\begin{array}{c}\text { Gastrointes- } \\
\text { tinal tract }\end{array}$ & 3 & 1 & 2 & 0 & 3 \\
\hline Nephrology & 2 & 1 & 1 & 0 & 2 \\
\hline $\begin{array}{l}\text { Reproduc- } \\
\text { tion system }\end{array}$ & 8 & 7 & 1 & 1 & 7 \\
\hline $\begin{array}{c}\text { Endocrino- } \\
\text { logy }\end{array}$ & 3 & 2 & 1 & 0 & 3 \\
\hline Hematology & 1 & 1 & 0 & 0 & 1 \\
\hline $\begin{array}{c}\text { Musculo- } \\
\text { skeletal }\end{array}$ & 2 & 2 & 0 & 0 & 2 \\
\hline Integument & 6 & 2 & 4 & 1 & 5 \\
\hline $\begin{array}{c}\text { Others } \\
\text { (pediatric) }\end{array}$ & 5 & 4 & 1 & 0 & 5 \\
\hline $\begin{array}{c}\text { Others } \\
\text { (adult and } \\
\text { emergency) }\end{array}$ & 12 & 11 & 1 & 2 & 10 \\
\hline Forensic & 2 & 2 & 0 & 0 & 2 \\
\hline $\begin{array}{l}\text { Community } \\
\text { medicine }\end{array}$ & 9 & 4 & 5 & 2 & 7 \\
\hline Total & 63 & $\begin{array}{c}43 \\
(68.25 \\
\%) \\
\end{array}$ & $\begin{array}{c}20 \\
(31.75 \%)\end{array}$ & $7(11.11 \%)$ & $\begin{array}{c}56 \\
(88.89 \%)\end{array}$ \\
\hline
\end{tabular}

TABLE VII. FACTORS EFFECTED STUDENTS COULD NOT IMPLEMENT CLINICAL SKILLS AT PHC

\begin{tabular}{|l|c|c|}
\hline \multicolumn{1}{|c|}{ Effecting Factors } & $\begin{array}{c}\text { Number of } \\
\text { cases }\end{array}$ & \% \\
\hline Limited drugs & 21 & 22.11 \\
\hline Limited tools/equipment & 17 & 17.89 \\
\hline $\begin{array}{l}\text { Limited time/overload patients/doctors } \\
\text { were too busy }\end{array}$ & 16 & 16.84 \\
\hline Unconfident doctors/health workers & 15 & 15.79 \\
\hline Patient rejecting medical intervention & 13 & 13.68 \\
\hline Others & 13 & 13.68 \\
\hline Total & 95 & 100.00 \\
\hline
\end{tabular}


Table VII showed the major factors that affecting implementation clinical skill in PHC were limited drugs and tools also infrastructures (21 and 17 of total 95 cases). Unfortunately, in 13 cases patients rejected some medical intervention for example blood laboratory examination.

\section{DISCUSSION}

Students stated that mostly all clinical skills had been taught during preclinical and clinical phase. It was good evidence, since we know that the more involvement in teaching (both preclinical and clinical phase), the higher students' clinical performance [6].

Clinical skills that student had less experience to implement was making diagnosis and proposing additional examination. The five clinical skills mentioned above could not stand alone, those skills related each other. If one of the clinical skills was not done well, it will affect the patient's quality management outcome. Making a diagnosis requires patient's interview, physical examination, and also perform additional examination. In order to do physical examination and additional examination such as blood or urine laboratory examination, it needs medical tools/equipment and reagents. As shown in results, in most cases, students had not implemented their clinical skills at PHC, it might be due to limited tools and infrastructures. Another reason was the cases faced in primary care are generally mild, so it was sufficient to do anamnesis and physical examination and did not require any additional examination to make the diagnosis. Furthermore, to perform patient management required drugs. When the availability of drugs was limited, this would certainly impact students could not optimally provide treatment to patients.

For clinical skills implementation, students revealed that most of clinical skills had not been implemented at PHC during their 5 weeks rotation. It was opposite with findings from G. Kayingo in 2015, that from 179 students almost all students conducted communication, physical examination, and treatment, but less involvement in billing or care coordination and quality improvement project during their primary care rotation [7]. In one study in US, students experienced more patient interaction in community setting compared to hospital setting, thus students had more opportunities to sharp their clinical skills [8]. For communication and education skills students stated that they implemented $50 \%$ of total communication cases. Performing communication skills does not require medical tools or reagents, so students were able to do this clinical skill with limited resources. The constraint of implementation of communication skills was overload of patients, so students did not have sufficient time to communicate and education comprehensively to patients.

To perform all clinical skills, from communication and education skills until providing appropriate therapy to patients, students must master medical knowledge. The other reason why students did not applying clinical skills was lack of medical knowledge. As we know that medical knowledge (both basic and clinical sciences) is a fundamental to do clinical skills $[9,10]$.

Limitations of this study were first, data collection in this study was only 5 weeks at 10 PHC, and based on experience of student groups (not individual students), so the cases encountered by students are limited. Second, the list of clinical skills listed in this study was still limited.

This study provided good feedback to medical institution and government. For medical institution it is recommended to cover some clinical skills that students have not been taught. For government should improve availability of drugs, tools/equipment in PHC.

\section{CONCLUSION}

Despite students revealed that most of clinical skill had been taught during academic and clinical phase, they were lack of diagnosis and proposing additional examination implementation in PHC during community medicine rotation. The most factors affected were limited drugs and tools/equipment.

\section{ACKNOWLEDGMENT}

We thank to all students and primary health center staffs in Tangerang District that have helped this study conducted.

\section{REFERENCES}

[1] Ministry of Health of Republic Indonesia. Socialization Guidance Book National Health Coverage in National Social Coverage System/Buku Pegangan Sosialisasi Jaminan Kesehatan Nasional dalam Sistem Jaminan Sosial Nasional, 2013, pp. 1-75.

[2] Indonesia Medical Council. Indonesia Doctor Competency Standard/Standar Kompetensi Dokter Indonesia, 2012, p.5.

[3] C. Nikendei, et all. "Modification of Peyton's four-steps approach for small group teaching-a descriptive study," BMC Medical Education, vol. 14, pp. 68, April 2014.

[4] J.H. George, F.X. Doto. A Simple Five Step Method for Teaching Clinical Skills"' Family Medicine, vol. 33(8), pp. 577-578, 2001.

[5] G.R. Retno, et al. "Large-scale multi-site OSCEs for national competency examination of medical doctors in Indonesia," Medical Teacher, vol. 38(8), pp. 801-807, August 2016.

[6] J.M. Lockyer et al. "Clinical teaching as part of continuing professional development: Does teaching enhance clinical performance?" Medical Teacher, vol. 38(8), pp. 815-822, August 2016.

[7] G. Kayingo, V. Deon Kidd, O. Gilani, M.L. Warner. "Primary Care Teams, Composition, Roles, and Satisfaction of PA Students During Primary Care Rotations," Journal Physician Assisstant Education, vol. 26(2), pp. 88-92, June 2015.

[8] A.N. Poncelet, et al. "Creating a Longitudinal Integrated Clerkship with Mutual Benefits for an Academic Medical Center and a Community Health System," The Permanente Journal, vol 18(2), pp. 50-56, Spring 2014.

[9] E. van Gessel, et al. "Development of clinical reasoning from the basic sciences to the clerkships: a longitudinal assessment of medical students' needs and self-perception after a transitional learning unit," Medical Education, vol. 37, pp. 966-974, 2003.

[10] E.H. Duthie Jr, et al. "A collaborative strategy for reciprocal integration of basic and clinical sciences.," Medical Science Educator, vol. 14(1), pp. 34-38, 2004. 